\title{
AN INTERPRETIVE TURN TO PRACTICE?
}

\author{
Daniel Peat ${ }^{*}$ \\ Matthew Windsor ${ }^{\dagger}$
}

In August 2013, the Lauterpacht Centre for International Law and the Faculty of Law at the University of Cambridge hosted a conference on the theme Interpretation in International Law. As conveners of the conference, we were delighted with the response to our call for papers, and the creative insights brought to bear on a perennially popular subject in the theory and practice of public international law. The keynote speakers included Professor Philip Allott, ${ }^{1}$ Judge Sir David Baragwanath, ${ }^{2}$ Professor Andrea Bianchi, ${ }^{3}$ and Associate Professor Ingo Venzke, ${ }^{4}$ and sessions were ably chaired by the likes of Professor James Crawford AC SC 5 and Sir Michael Wood. ${ }^{6}$ In their presentations and discussions, we urged the many distinguished academics and practitioners in attendance to consider who has or claims to have the authority to interpret in international law, and how actors within the international legal system advance these claims. Rather than concentrating on textual interpretation or doctrinal exposition, we considered that the identity of the interpreters and the epistemic communities involved in interpretation should be foregrounded.

The exceptional quality of the papers presented at the conference has given rise to two major scholarly outputs: an edited collection titled Interpretation in International Law, to be published by Oxford University Press in 2015; ${ }^{7}$ and this symposium, focusing on interpretation in the context of international adjudication.

The proliferation of international courts and tribunals in recent times has given rise to a juridification of international relations, and has significantly al-

\footnotetext{
PhD Candidate, Gonville \& Caius College, University of Cambridge.

+ PhD Candidate, Gonville \& Caius College, University of Cambridge.

1 Emeritus Professor of International Public Law, University of Cambridge.

2 President, Special Tribunal for Lebanon.

3 Professor, The Graduate Institute of International and Development Studies, Geneva.

4 Associate Professor, University of Amsterdam.

5 Whewell Professor of International Law, University of Cambridge.

6 Barrister, 20 Essex Street; Member, International Law Commission.

7 A Bianchi, D Peat \& M Windsor (eds), Interpretation in International Law (2015, in press).
}

Copyright $\odot$ the Author(s).

This work is licensed under a Creative Commons Attribution-NonCommercial-NoDerivs 3.0 License. 
tered the landscape of global governance. ${ }^{8}$ Although the process of judicialisation has been described as 'uneven,', international adjudication has had an increasing part to play in facilitating the peaceful settlement of disputes. ${ }^{10}$ However, the international adjudication 'progress narrative' has resulted in a range of interpretive dilemmas, frequently discussed in terms of regime interaction and fragmentation. ${ }^{11}$ The growth of international adjudication has given rise to a greater range of actors engaged in the battle for 'semantic authority' that characterises the practice of interpretation in international law. ${ }^{12}$ Accordingly, it has become increasingly imperative to closely analyse the interpretive approaches adopted by different international courts and tribunals. ${ }^{13}$ Given that international courts and tribunals inevitably 'develop their own hermeneutics,', ${ }^{14}$ a myopic focus on the rules of the Vienna Convention on the Law of Treaties is no longer sufficient to tackle the complexities of interpretation in international adjudication.

In the first two Articles of this symposium, interpretation in international adjudication is considered in the context of the Special Tribunal for Lebanon (STL), the Court of Justice of the European Union (CJEU) and the WTO Appellate Body by authors working within those institutions. If 'international law is what international lawyers do and how they think', as Martti Koskenniemi contends, ${ }^{15}$ we are fortunate to be privy to such candid analyses of the interpretive inner-workings in the aforementioned adjudicatory bodies.

${ }^{8}$ See e.g., C Romano, K Alter \& Y Shany (eds), The Oxford Handbook of International Adjudication (2013); K Alter, The New Terrain of International Law: Courts, Politics, Rights (2014); C Brown, A Common Law of International Adjudication (2007); A von Bogdandy \& I Venzke, In Whose Name? A Public Law Theory of International Adjudication (2014, in press); and A Paulus, 'International Adjudication' in S Besson \& J Tasioulas (eds), The Philosophy of International Law (2010) 207.

9 B Kingsbury, 'International courts: uneven judicialisation in global order' in J Crawford \& M Koskenniemi (eds), The Cambridge Companion to International Law (2012) 203, 211-15.

${ }^{10} \mathrm{~J}$ Klabbers, International Law (2013) 163.

${ }^{11}$ For differing perspectives, see UN International Law Commission, Fragmentation of International Law: Difficulties Arising from the Diversification and Expansion of International Law, UN Doc. A/CN.4/L.682, 13 April 2006; P Webb, International Judicial Integration and Fragmentation (2013); A Nollkaemper \& O Fauchald (eds), The Practice of International and National Courts and the (De-)Fragmentation of International Law (2012); and M Young (ed), Regime Interaction in International Law: Facing Fragmentation (2012).

${ }^{12}$ I Venzke, How Interpretation Makes International Law (2012) 62-4.

${ }^{13}$ See e.g., J Pauwelyn \& M Elsig, "The Politics of Treaty Interpretation: Variations and Explanations across International Tribunals', in J Dunoff \& M Pollack (eds), Interdisciplinary Perspectives on International Law and International Relations: The State of the Art (2013) 445.

${ }^{14}$ Kingsbury, above n 9, 204.

${ }^{15}$ M Koskenniemi, 'Between Commitment and Cynicism: Outline of a Theory of Law as Practice', in The Politics of International Law (2011) 271, 293. 
In an article based on his keynote address, Judge Sir David Baragwanath, the President of the STL, reflects on the challenges of interpretation in international adjudication across the common law/civil law divide. The ability to bridge these legal traditions assumes particular relevance in the STL, the controversial UNsponsored international criminal tribunal tasked with applying the substantive criminal law of Lebanon. ${ }^{16}$ Baragwanath, whose professional background is as a common law judge, ${ }^{17}$ provides an illuminating discussion of the relationship between interpretation and international law-making, the tensions between interpretive certainty and flexibility, and the need for an interpretive test predicated on the 'highest standard of practical necessity'. He contends that the interpreter must examine legal issues 'through a periscope that lifts one's vision beyond the confines of our own particular experience', enabling one to select the path that most readily responds to the exigencies of the case at hand. Baragwanath argues that common law and civilian legal traditions share origins and aims that often help unite their approach across the interpretive divide; it is the adherence to these values that form the bedrock of the interpretive approach of the STL.

The following article deals with treaty interpretation in the CJEU and the WTO Appellate Body. Authored by Andreas Sennekamp and Isabelle Van Damme, ${ }^{18}$ a Counsellor at the WTO Appellate Body Secretariat and Référendaire at the CJEU respectively, this contribution provides the reader with a valuable insider's perspective into the interpretive practices of the two institutions. The article begins by providing a general background to the adjudicatory practices of the CJEU and the Appellate Body, highlighting elements of the institutional context that shape the judicial function of each tribunal. The interpretive approaches of the CJEU and the Appellate Body are often juxtaposed in academic analysis; the former noted for its teleological approach and attachment to effectiveness, and the latter for adopting a strict textualist approach. ${ }^{19}$ Moving away from a simplistic analysis that attributes this divergence to fundamentally

\footnotetext{
${ }^{16}$ See generally A Alamuddin, N N Jurdi and D Tolbert (eds), The Special Tribunal for Lebanon: Law and Practice (2014).

${ }^{17}$ Prior to joining the STL, Judge Sir David Baragwanath was a Judge of the Court of Appeal of New Zealand.

${ }^{18}$ See also I van Damme, Treaty Interpretation by the WTO Appellate Body (2009). See M Waibel, 'Demystifying the Art of Interpretation' (2011) 22 EJIL 571, 588: 'With this book at hand, there is no risk that the novice, much less the cognoscenti, will miss the forest for the trees'.

${ }^{19}$ See e.g., N Fennelly, 'Legal Interpretation at the European Court of Justice' (1996) 20(3) Fordham ILJ 656, 664. Cf W Magnuson, 'WTO Jurisprudence and its Critiques: The Appellate Body's Anti-Constitutional Resistance' (2010) 51 Harvard ILJ Online 121, 124-29: '[The interpretive approach of the Appellate Body] is textualism run amok'
} 
different views regarding the rules of treaty interpretation, Sennekamp and Van Damme attempt to frame the interpretive practice of each adjudicatory body within their respective institutional contexts, arguing that legal and extra-legal constraints must be borne in mind when analysing the approaches that the CJEU and Appellate Body adopt. The linguistic and procedural practices of the adjudicatory body, as well as the character of the legal text, frame the approach to treaty interpretation that each body takes. The methodology of this article is a timely reminder that interpretation cannot, and should not, be divorced from the context in which it occurs.

The final three articles in the symposium all deal with interpretation in the context of international human rights adjudication.

Shai Dothan's article explores the phenomenon, and permissibility, of expansive interpretation by the European Court of Human Rights. Expansive interpretation refers to the interpretive techniques employed by the Court to expand states' human rights obligations beyond the obligations states undertook when ratifying the Convention. Although expansive interpretation has been challenged on the basis that it undermines the democratic decisions of signatory states, Dothan examines two contexts in which expansive interpretation is consistent with democratic theory: first, when the refusal by a small group of states to amend the Convention means that the democratic will of representative states is not fully reflected in the treaty text; and second, in situations where states misrepresent the interests of individuals affected by their human rights policies, including individuals who cannot vote and 'discrete and insular minorities. ${ }^{20}$ In such situations, Dothan argues that expansive interpretation is a necessary corrective to democratic failure and enhances the Court's normative legitimacy. ${ }^{21}$ For Dothan, an expansive interpretive posture may have purchase in other international adjudication contexts, where states' treaty obligations do not represent the views of states and their citizens.

Jure Vidmar's article is a searching analysis of the interpretation of democracy in judicial practice as opposed to political theory. ${ }^{22}$ It focuses on judicial interpretation of the so-called 'democratic rights' in a range of human rights treaties including the International Covenant on Civil and Political Rights, the European

\footnotetext{
${ }^{20}$ United States $v$ Carolene Products Co, 304 US 144 (1938).

${ }^{21}$ For further discussion of judicial tactics employed by international courts to maximize their reputational gains, see S Dothan, Reputation and Judicial Tactics: A Theory of National and International Courts (2015, in press).

${ }^{22}$ See also J Vidmar, Democratic Statehood in International Law: The Emergence of New States in Post-Cold War Practice (2013).
} 
Convention for the Protection of Human Rights and Fundamental Freedoms, the American Convention on Human Rights, and the African Charter on Human and Peoples' Rights. Although the wording of the rights in each instrument is almost identical, international courts have developed different understandings of democracy through interpretation, in the absence of an authoritative definition. Vidmar demonstrates that judicial interpretation of the right to political participation has resulted in multi-party elections being prescribed as the preferred institutional setting in international human rights law. Indeed, some courts have limited the possibility of independent candidates participating outside the party politics framework. Vidmar also canvasses a more substantive conception of democracy that is emerging through judicial interpretation of the 'necessary in a democratic society' limitation clause, whereby exercise of the democratic rights is limited in order to protect democracy. Thus, the article cogently highlights the role of international adjudication in interpreting legal obligations generated by the principle of democracy.

In the final article of the symposium, Diane Desierto and Colin Gillespie address the interpretation of the International Covenant on Economic, Social and Cultural Rights (ICESCR) by a pluralist community of institutional interpreters including the Committee on Economic, Social and Cultural Rights, and a range of international and national courts and tribunals. Desierto and Gillespie articulate an interpretive paradigm for the authoritative determination of international responsibility for violations of ICESCR. They focus on normative justiciability (the precision of ICESCR rights and amenability of application by judicial or quasi-judicial bodies) and institutional justiciability (the competence of a tribunal to adjudicate or assess violations of Covenant rights). In terms of normative justiciability, the authors foreground the 'minimum core content' of ICESCR obligations that are jointly determined by each State Party with the Committee upon accession, in conjunction with the principles of non-discrimination, non-retrogression and progressive realisation. Regarding institutional justiciability, the authors argue that the proliferation of authoritative interpreters explains the diversity of forms of relief granted for ICESCR violations. Desierto and Gillespie's comprehensive analysis of interpretive practice under ICESCR is both timely and instructive, in the context of a symposium on international adjudication: timely, given the recent quasi-adjudicative competences conferred on the Committee under the ICESCR's Optional Protocol; ${ }^{23}$ and instructive, in its

\footnotetext{
${ }^{23}$ The Optional Protocol to the International Covenant on Economic, Social and Cultural Rights entered into force on 5 May 2013. See also D Desierto \& C Gillespie, 'Evolutive Interpretation
} 
salutary reminder that the interpretation of international law norms is not the exclusive domain of international adjudication. ${ }^{24}$

The majority of the articles in the Symposium demonstrate the analytic value of a 'turn to practice' when considering interpretation in international adjudication. ${ }^{25}$ The extensive practical experience of Baragwanath, Sennekamp and Van Damme is brought to bear in their rich discussion of interpretation in the STL, the WTO Appellate Body and the CJEU. Meanwhile, Vidmar, Desierto and Gillespie orient their discussion around a detailed consideration of interpretive practice. However, the value of theory in the context of interpretation in international law has not diminished, as evidenced by our forthcoming co-edited book on the subject. ${ }^{26}$ As Anne Peters has argued, international legal scholarship can 'support practice by pursuing a via media between infertile alienation from and fetishism with practice. ${ }^{27}$ Dothan's chapter exemplifies the enduring virtue of doctrinal analysis complemented by theoretical research, in his transposition of democratic theory from the domestic constitutional context to a consideration of the appropriate interpretive posture of the European Court of Human Rights.

The Interpretation in International Law conference and this symposium would not have been possible without the help of many. We thank the symposium authors for their articles; the other speakers and session chairs at the conference; our sponsors including Oxford University Press, Cambridge University Press, Hart Publishing, Ashgate and Gonville \& Caius College; and the CJICL editorial team for their assistance.

and Subsequent Practice: Interpretive Communities and Processes in the Optional Protocol to the ICESCR' (2013) 73 ZaöRV 549.

${ }^{24}$ J Dunoff \& M Pollack, 'Reviewing Two Decades of IL/IR Scholarship: What We've Learned, What's Next' in J Dunoff \& M Pollack (eds), Interdisciplinary Perspectives on International Law and International Relations: The State of the Art (2013) 626, 635-6.

${ }^{25}$ Johns discusses the 'turn to practice' as follows: 'an orientation towards knowledge practices is associated less with analysis of inputs and outputs or causes and effects, than with immanent, critical investigation of the patterned activities and often mundane modes of work in which social knowledge-makers engage': F Johns, Non-Legality in International Law (2013) 23.

${ }^{26}$ Bianchi, Peat \& Windsor, above $\mathrm{n} 7$.

${ }^{27}$ A Peters, 'Realizing Utopia as a Scholarly Endeavour' (2013) 24 EJIL 533, 533. 